\title{
Homocystein og livsstil Resultater fra Homocysteinundersøkelsen i Hordaland 1992-1993
}

\author{
Ottar Nygård $^{1}$, Helga Refsum ${ }^{2}$, Per Magne Ueland $^{2}$, Aage Tverdal $^{3}$, Stein Emil Vollset ${ }^{1}$ \\ ${ }^{I}$ Seksjon for medisinsk statistikk og dataanalyse, Institutt for samfunnsmedisinske fag, Universitetet i Bergen \\ ${ }^{2}$ Institutt for Farmakologi, Universitetet i Bergen \\ ${ }^{3}$ Statens helseundersøkelser, Oslo
}

Korrespondanse til: Ottar Nygård, Hjerteavdelingen, 5021 Haukeland Sykehus

Telefon: 55972220 Telefaks: 55975150

\begin{abstract}
SAMMENDRAG
Total homocystein (tHcy) er etablert som risikofaktor for hjerte- og karsykdom. Vi har studert determinanter av plasma tHcy i et utvalg av den voksne norske befolkning basert på undersøkelse utført av Statens helseundersøkelser i samarbeid med Universitetet i Bergen i 1992-1993. Data ble innhentet ved klinisk undersøkelse, utfylling av tre spørreskjema og ved blodtester. I alt 18043 personer i alderen 40-67 år møtte til undersøkelse og fikk målt plasma tHcy. Plasma folat, plasma kobalamin og $677 \mathrm{C} \rightarrow$ T mutasjonen i genet for metylentetrahydrofolatreduktase (MTHFR) er bestemt i et underutvalg på 329 personer og på personer med svært høye tHcy verdier $(\geq 40 \mu \mathrm{mol} / \mathrm{L})$. Resultatene fra Homocysteinundersøkelsen i Hordaland har vist at kjønn, alder, folatinntak, røykevaner og kaffeforbruk er de sterkeste determinanter for plasma tHcy nivå, mens kobalamininntak, fysisk aktivitet, blodtrykk og kolesterolnivå er mindre sterke determinanter. Bruk av multivitaminer eller B-vitaminer er forbundet med spesielt lave tHcy nivåer. Personer med tHcy $\geq$ $40 \mu \mathrm{mol} / \mathrm{L}$ er karakterisert ved høy forekomst $(73 \%)$ av homozygositet for $677 \mathrm{C} \rightarrow \mathrm{T}$ mutasjonen i MTHFR genet og lavt folatnivå. Vi konkluderer derfor med at livsstil og etablerte risikofaktorer for hjerte- og karsykdom er vesentlige for nivået av plasma tHcy i den generelle voksne norske befolkning.
\end{abstract}

\section{Nygård O, Refsum H, Ueland PM, Tverdal A, Vollset SE. Homocysteine and lifestyle. The Hordaland \\ Homocysteine Study. Nor J Epidemiol 1997; 7 (2): 221-224.}

\section{ENGLISH SUMMARY}

Total homocysteine (tHcy) concentration is an established cardiovascular risk factor. We have studied determinants of plasma tHcy among 18043 subjects aged 40-67 years from Hordaland county in Western Norway who participated in a health screening programme in 1992-1993. Gender, age, folate intake, smoking habits and coffee consumption are the strongest determinants of plasma tHcy level, whereas cobalamin intake, physical activity, blood pressure and total cholesterol level are weaker determinants. Use of multivitamins or B-vitamin supplements are associated with particularly low tHcy levels. In patients with severely elevated tHcy ( $\geq 40 \mu \mathrm{mol} / \mathrm{L}, \mathrm{n}=67$ ), the combination of homozygosity for the $677 \mathrm{C} \rightarrow \mathrm{T}$ mutation in the methylenetetrahydrofolate gene and low plasma folate levels is a dominant finding whereas a minor proportion has overt cobalamin deficiency. We conclude that lifestyle and established cardiovascular risk factors are important determinants of the plasma tHcy level in an adult Norwegian population.

\section{INTRODUKSJON}

Svovelaminosyren homocystein (Hcy) finnes i blodet i forskjellige former, og summen av disse formene betegnes total homocystein (tHcy). Konsentrasjonen av tHcy måles vanligvis i plasma eller serum og er oftest mellom 5-15 $\mu \mathrm{mol} / \mathrm{L}$ (1). tHcy er nå etablert som en sensitiv markør på kobalamin- eller folatmangel $(2,3)$.
Den sjeldne medfødte stoffskiftesykdommen homocystinuri er modellsykdom for sammenhengen mellom Hcy/tHcy og hjerte- og karsykdom. Disse pasientene har alvorlig forhøyet tHcy $(>100 \mu \mathrm{mol} / \mathrm{L})$, og ubehandlet opplever $50 \%$ en tromboembolisk komplikasjon og 20\% dør før 30 års alder (4).

Resultatene fra mer enn 80 observasjonsstudier gjennom de siste 20 år viser at også moderat forhøyet 
tHcy/Hcy er forbundet med økt risiko for sykdom i det cerebrale, koronare og perifere karsystem $(5,6)$. For pasienter med etablert koronarsykdom har vi dessuten nylig vist at totaldød er sterkt assosiert med tHcynivået (7).

Hcy dannes fra den essensielle aminosyren metionin. Forhøyet tHcy skyldes genetiske og ervervete faktorer (4). Blant genetiske faktorer har $677 \mathrm{C} \rightarrow \mathrm{T}$ mutasjonen i genet for enzymet metylentetrahydrofolatreduktase (MTHFR) fått stor oppmerksomhet da den er hyppig forekommende $(\sim 10 \%)$ i den hvite befolkningen og medfører redusert aktivitet av enzymet som tilbakedanner Hcy til metionin (8). Lav folatstatus eller kobalaminstatus er ervervete faktorer som gir høyt tHcy nivå da disse vitaminer inngår direkte i Hcymetabolismen (4).

I denne undersøkelsen har vi studert determinanter av plasma tHcy i et utvalg som antas å være representativt for den voksne norske befolkning. Resultatene som presenteres er et sammendrag av data som er omtalt $i$ andre artikler (9-14).

\section{BEFOLKNINGSUNDERSØKELSEN}

Homocysteinundersøkelsen i Hordaland ble gjennomført i 1992-93, og er den første store befolkningsundersøkelsen der tHcy-nivået er blitt kartlagt i stor skala (9). Undersøkelsen var et samarbeid mellom Universitetet i Bergen og Statens helseundersøkelser og hadde som mål å kartlegge risikofaktorer for hjerte- og karsykdommer. I alt 24815 voksne hordalendinger i alderen 40-67 år ble invitert til å delta; alle 40-42 åringer i Hordaland, et 2\% utvalg av 43-64 åringene i Bergen, og alle 65-67 åringene i Bergen og 3 nabokommuner. I alt $18043(72,7 \%)$ av de inviterte møtte og fikk utført bestemmelse av plasma tHcy. Data ble innhentet gjennom klinisk undersøkelse, utfylling av tre spørreskjema og ved blodanalyser. I tillegg til plasma tHcy, ble serum kolesterol og triglycerider analysert for alle deltagerne. Plasma folat og kobalamin samt prevalensen av $677 \mathrm{C} \rightarrow \mathrm{T}$ mutasjonen i MTHFR genet ble bestemt på et underutvalg bestående av 329 personer og på alle med svært høye tHcy verdier ( $\geq 40$ $\mu \mathrm{mol} / \mathrm{L}$ ). Variasjon i kobalaminstatus og folatstatus for hele studiepopulasjonen ble estimert ved at en utviklet henholdsvis en kobalaminscore og en folatscore. Disse scorer var basert på hyppigheten av inntak av matvarer og eventuelt vitamintilskudd, og ble validert ved å studere determinanter for plasma folat og plasma kobalamin i underutvalget (11).

Da sykdom kan endre vaner og livsstil som er knyttet til plasma tHcy nivået, valgte vi å ekskludere i alt 1866 personer behandlet for hypertensjon, diabetes mellitus, koronarsykdom eller cerebrovaskulær sykdom og 1 person med homocystinuri fra alle andre analyser enn de som ligger til grunn for Tabell 1.
Tabell 1. Antall inviterte, antall deltagere og plasma total homocystein (tHcy) ${ }^{1}$ etter alder og kjønn.

\begin{tabular}{|c|c|c|c|}
\hline Alder og kjønn & $\begin{array}{c}\text { Antall } \\
\text { inviterte }\end{array}$ & $\begin{array}{c}\text { Antall } \\
\text { deltagere }\end{array}$ & $\begin{array}{c}\mathrm{tHcv} \\
\mu \mathrm{mol} / \mathrm{L}\end{array}$ \\
\hline \multicolumn{4}{|l|}{$40-42 \stackrel{a}{\mathrm{r}}$} \\
\hline Kvinner & 8316 & 6485 & 9,6 \\
\hline Menn & 8987 & 6110 & 11,4 \\
\hline \multicolumn{4}{|l|}{ 65-67 ̊r } \\
\hline Kvinner & 3508 & 2639 & 11,6 \\
\hline Menn & 3005 & 2127 & 13,0 \\
\hline Totalt $^{2}$ & 24815 & 18043 & 13,0 \\
\hline $\begin{array}{l}{ }^{1} \text { Verdier for arit } \\
\text { verdier for geom } \\
\text { lavere. }\end{array}$ & $\begin{array}{l}\text { k gjen } \\
\text { k gjenr }\end{array}$ & $\begin{array}{l}\text { nitt er pr } \\
\text { nitt var c }\end{array}$ & $\begin{array}{l}\mathrm{ert} ; \\
\mu \mathrm{mol} / \mathrm{L}\end{array}$ \\
\hline
\end{tabular}

TVERRSNITTSRELASJONER TIL HOMOCYSTEIN

\section{Kjonn og alder}

Distribusjonskurven av tHcy var tydelig skjevfordelt med en lang hale av høye tHcy-verdier i alle de fire kjønns- og aldersgruppene i undersøkelsen. Av den grunn var geometriske gjennomsnittsverdier av tHcy ca $0,5 \mu \mathrm{mol} / \mathrm{L}$ lavere enn de aritmetiske gjennomsnitt (9). Tabell 1 gir en oversikt over antall inviterte, antallet som møtte og plasma tHcy i disse hovedgruppene. Det fremgår at plasma tHcy er $2 \mu \mathrm{mol} / \mathrm{L}$ lavere hos kvinner enn hos menn i aldersgruppen 40-42 år, og at tHcy nivået var opptil $2 \mu \mathrm{mol} / \mathrm{L}$ høyere $\mathrm{i}$ aldersgruppen 65-67 år. Økningen av tHcy med økende alder var størst hos kvinner, slik at forskjellen i tHcy mellom kjønnene var redusert til 1,6 $\mu \mathrm{mol} / \mathrm{L}$ i den eldste aldersgruppen. Undersøkelsen bekrefter resultater fra tidligere mindre studier om at tHcy-nivået er avhengig av kjønn og alder (15) og antyder at kvinnelige kjønnshormoner spiller en rolle for tHcy nivået.

\section{Royking}

Plasma tHcy var høyere hos røykere enn hos ikkerøykere med en klar dose-respons som var nesten dobbelt så sterk hos kvinner som hos menn; hos 40-42 år gamle kvinner ble det beregnet en ca. 2\% økning i tHcy per sigarett (9). Det var ingen tydelig forskjell i tHcy nivået mellom tidligere røykere og de som aldri hadde røykt. Blant røykerne var nivået uavhengig av antall røykeår, mens det hos tidligere røykere ble funnet noe høyere verdier hos de som hadde høyest antall røykeår før de sluttet. Relasjonen mellom røykestatus og tHcy ble kun i liten grad svekket ved justering for variasjon $\mathrm{i}$ folat- eller kobalaminstatus. 


\section{Fysisk aktivitet, blodtrykk, kolesterol og alkoholinntak}

Plasma tHcy viste en invers relasjon til graden av fysisk aktivitet i fritiden, mens det ble funnet en positiv relasjon både til systolisk og diastolisk blodtrykk, hjertefrekvens og kolesterolnivå (9). I multivariate analyser var forskjellen i tHcy mellom ekstremgrupper av de nevnte variable mindre enn $1 \mu \mathrm{mol} / \mathrm{L}$. Til sammenligning var den multivariate forskjellen mellom storrøykerne ( $\geq 20$ sigaretter per dag) og de som aldri hadde røykt mer enn dobbelt så stor. Det ble ikke funnet noen samvariasjon mellom plasma tHcy og kroppsmasseindeks eller serum triglycerider. Derimot ble det funnet en U-formet sammenheng mellom alkoholinntak og tHcy med lavest tHcy nivå hos personer med et inntak på 7-13 enheter alkohol per uke (14). Variasjonen i tHcy etter alkoholinntak var sterkest hos røykere.

\section{Kaffe og te}

Vi fant en overraskende sterk sammenheng mellom kaffeinntak og plasma tHcy (10). I alt $89 \%$ av deltagerne drakk kaffe daglig, og $95 \%$ av disse brukte filterkaffe. Selv om det var få som brukte andre typer kaffe, ble det funnet en signifikant positiv kaffe-tHcy relasjon også for drikkere av kokekaffe og pulverkaffe, men ikke av dekaffeinert kaffe. Sammenhengen mellom tHcy og kaffeinntak var nesten like sterk som mellom tHcy og røyking. Kritikere av hypotesen om Hcy som en viktig årsaksfaktor til hjerte- og karsykdom vil kanskje hevde at kaffe-tHcy relasjonen peker imot en slik årsakssammenheng da kaffe er en svakere risikofaktor enn røyking. Denne undersøkelsen har imidlertid avdekket noen forhold som kan bidra til å forklare denne forskjell. Mens røyking var assosiert med en fullstendig høyreforskyvning av distribusjonskurven for tHcy, var inntak av kaffe ikke relatert til høye nivå (> 95 percentilen; ca. $17 \mu \mathrm{mol} / \mathrm{L})$. I tillegg ble det funnet forskjeller mellom røyking og kaffe når det gjelder deres relasjoner til andre tioler enn tHcy (upubliserte data). Det kan også tenkes at andre karakteristika enn selve kaffedrikkingen i en befolkning kan forklare det manglende samsvar i resultatene fra tidligere studier som har undersøkt sammenhenger mellom kaffeinntak og sykdom. Variasjon i folatstatus vil være en slik faktor. At røykevaner og kaffeinntak viste forskjeller i relasjonen til tHcy, kan tyde på at de tilgrunnliggende mekanismer er forskjellige (13).

Inntak av te viste en sterk invers relasjon til plasma tHcy i univariate analyser (10). Etter justering for røykevaner og kaffeinntak var det imidlertid ikke lenger noen signifikant sammenheng.

\section{Kosthold og vitamintilskudd}

Inntak av skummet og lett melk, fersk og frosset fisk, kjøtt og innmat var samlet de produkter som var sterkest relatert til variasjonen i plasma kobalaminnivået $i$ underutvalget på 329 personer. Disse matvarene inngikk derfor i kobalaminscoren som var en tydelig determinant for plasma tHcy i studiepopulasjonen (11). Inntak av frukt, grønnsaker, appelsiner, fruktjuice, egg og kjøtt var samlet de matvarer som var sterkest relatert til plasma folat. Bruk av multivitaminer eller B-vitaminer var imidlertid en enda sterkere determinant for plasma tHcy enn den estimerte variasjon i folatinntak fra kosthold. Dette kan tyde på at inntaket av folat i kosten i befolkningen i Hordaland er for lavt til å opprettholde en optimal metabolisme av Hcy. Når variasjon i folatstatus ble vurdert samlet (kosthold og vitamintilskudd), var denne folatscoren, ved siden av kjønn og alder, den sterkeste determinant av plasma tHcy i Hordaland-populasjonen.

\section{C $\rightarrow$ T MTHFR polymorfismen}

Som i studier fra mange andre vestlige land (8), ble det i underutvalget av vår studiepopulasjon funnet en prevalens av homozygositet for $677 \mathrm{C} \rightarrow \mathrm{T}$ mutasjon $\mathrm{i}$ MTHFR genet på ca $10 \%$ (12). Den tilsvarende mutasjonsfrekvensen blant de til sammen 67 personer som hadde plasma tHcy $\geq 40 \mu \mathrm{mol} / \mathrm{L}$ var $73,1 \%$ (12). Tidlige studier har vist at mutasjonen kun gir høyt tHcy nivå i kombinasjon med redusert folatstatus (16). Lavt plasma folat samt en stor andel røykere $(59,1 \%)$ var andre fremtredende karakteristika blant disse personene $\mathrm{i}$ vår studie (12). Kun en mindre andel hadde biokjemiske tegn på sikker kobalaminmangel.

\section{KONKLUSJON}

Risikoen for den enkelte til å utvikle hjerte- og karsykdom blir ofte vurdert gjennom en samlet vurdering av en rekke risikofakorer. Homocysteinundersøkelsen i Hordaland viser en påfallende samvariasjon mellom tHcy og en slik risikoprofil ettersom tHcy nivået er sterkt knyttet til livsstil. Нøyt tHcy er relatert til mannlig kjønn, høy alder, røyking, fysisk inaktivitet, høyt kolesterolnivå, høyt blodtrykk, høyt kaffeinntak og lavt inntak av frukt og grønnsaker, mens lavt nivå er knyttet til kvinnelig kjønn, ung alder, rikelig fysisk aktivitet, lave verdier for kolesterolnivå og blodtrykk, inntak av te i stedet for kaffe, høyt inntak av frukt og grønnsaker samt bruk av multivitaminer eller Bvitaminer. Homocystinuriene som modellsykdom gir homocysteinhypotesen biologisk plausibilitet, men det er foreløpig ikke etablert aksepterte biologiske mekanismer som forklarer sammenhengen mellom tHcy og hjerte- og karsykdom (17). Svar på randomiserte intervensjonsforsøk må avventes før vi sikrere kan konkludere med om Hcy også er årsaksfaktor i en slik sammenheng. 


\section{REFERANSER}

1. Ueland PM, Refsum H, Stabler SP, Malinow MR, Andersson A, Allen RH. Total homocysteine in plasma or serum. Methods and clinical applications. Clin Chem 1993; 39: 1764-1779.

2. Schneede J, Refsum H, Slørdal L, Svardal A, Ueland PM. Bestemmelse av homocystein og metylmalonsyre ved kobalaminmangel. Tidsskr Nor Lageforen 1991; 111: 450-455.

3. Savage DG, Lindenbaum J, Stabler SP, Allen RH. Sensitivity of serum methylmalonic acid and total homocysteine determinations for diagnosing cobalamin and folate deficiencies. Am J Med 1994; 96: 239-246.

4. Mudd SH, Levy HL, Skovby F. Disorders of transsulfuration. In: Scriver CR, Beaudet AL, Sly WS, Valle D, red. The metabolic and molecular bases of inherited disease, 1 ed. New York: McGraw-Hill, 1995: 12791327.

5. Boushey CJ, Beresford SAA, Omenn GS, Motulsky AG. A quantitative assessment of plasma homocysteine as a risk factor for vascular disease: Probable benefits of increasing folic acid intakes. J Am Med Assoc 1995; 274: 1049-1057.

6. Ueland PM, Refsum H. Forhøyet plasma-homocysteinnivå som kardiovaskulær risikofaktor. Tidsskr Nor Lageforen 1996; 116: 1661-1662.

7. Nygård O, Nordrehaug JE, Refsum H, Farstad M, Ueland PM, Vollset SE. Homocysteine levels and mortality in patients with coronary artery disease. $N$ Engl J Med 1997; 337: under trykking.

8. van der Put NMJ, Eskes TKAB, Blom HJ. Is the common $677 \mathrm{C} \rightarrow \mathrm{T}$ mutation in the methylenetetrahydrofolate reductase gene a risk factor for neural tube defects? A meta-analysis. Q J Med 1997; 90: 111-115.

9. Nygård O, Vollset SE, Refsum H, Stensvold I, Tverdal A, Nordrehaug JE, et al. Total plasma homocysteine and cardiovascular risk profile. The Hordaland Homocysteine Study. J Am Med Assoc 1995; 274: 1526-1533.

10. Nygård O, Refsum H, Ueland PM, Stensvold I, Nordrehaug JE, Kvåle G, et al. Coffee consumption and total plasma homocysteine: The Hordaland Homocysteine Study. Am J Clin Nutr 1997; 65: 136-143.

11. Nygård O, Refsum H, Ueland PM, Vollset SE. Major lifestyle determinants of plasma total homocysteine distribution: The Hordaland Homocysteine Study. 1997, Submitted.

12. Guttormsen AB, Ueland PM, Nesthus I, Nygård O, Schneede J, Vollset SE, et al. Determinants of vitamin responsiveness of intermediate hyperhomocysteinemia ( $\geq 40 \mu \mathrm{mol} / \mathrm{L}$ ). The Hordaland Homocysteine Study. $J$ Clin Invest 1996; 98: 2174-2183.

13. Refsum H, Nygård O, Kvåle G, Ueland PM, Vollset SE. The Hordaland Homocysteine Study: The opposite tails odds ratios reveal differential effects of gender and intake of vitamin supplements at high and low plasma homocysteine concentrations. J Nutr 1996; 126: 1244S-1248S.

14. Vollset SE, Nygård O, Kvåle G, Refsum H, Ueland PM. The Hordaland Homocysteine Study: Lifestyle and total plasma homocysteine in Western Norway. I Norwell MA, red. International conference on homocysteine metabolism: From basic science to clinical medicine. Kluwer Academic Publishers, 1997.

15. Andersson A, Brattström L, Israelsson B, Isaksson A, Hamfelt A, Hultberg B. Plasma homocysteine before and after methionine loading with regard to age, gender, and menopausal status. Eur J Clin Invest 1992; 22: 79-87.

16. Kang S-S, Zhou J, Wong PWK, Kowalisyn J, Strokosch G. Intermediate homocysteinemia: a thermolabile variant of methylenetetrahydrofolate reductase. Am J Hum Genet 1988; 43: 414-421.

17. Ubbink JB, Becker PJ, Vermaak WJH. Will an increased dietary folate intake reduce the incidence of cardiovascular disease? Nutr Rev 1996; 54: 213-216. 